\title{
Cryopreservation of testicular tissue: an alternative to maintain the reproductive capacity in different animal species
}

\author{
David Baruc Cruvinel Lima ${ }^{*}$ Lúcia Daniel Machado da Silva ${ }^{1}$
}

${ }^{1}$ Laboratório de Reprodução de Carnívoros, Universidade Estadual do Ceará (UECE), Campus do Itaperi, 60714-903, Fortaleza, CE, Brasil. E-mail: davidbarucvet@gmail.com. ${ }^{*}$ Corresponding author.

\begin{abstract}
Cryopreservation of testicular tissue enables the maintenance of reproductive capacity in different animal species, and contributes to the formation of gene banks for endangered species. The spermatogonia present in the testes can be grown in vitro and the sperm obtained can be used in artificial breeding programs. This review aimed to describe the main techniques of testicular cryopreservation, the main cryoprotectants used, as well as the progress made in different animal species thus far. In the last decade, significant progress has been made in obtaining viable and functional germ cells from testicular tissue. However, more research is needed to better establish protocols that can be used in clinical practice with various species.

Key words: testicle, conservation, cryoprotectants.
\end{abstract}

Criopreservação do tecido testicular: uma alternativa para manter a capacidade reprodutiva em diferentes espécies animais

RESUMO: A criopreservação do tecido testicular possibilita a manutenção da capacidade reprodutiva em diferentes espécies animais e contribui para a formação de bancos de germoplasma nas espécies ameaçadas de extinção. As espermatogônias presentes nos testículos podem ser cultivadas in vitro e os espermatozoides obtidos utilizados em programas de reprodução artificial. Assim, esta revisão teve como objetivo descrever as principais técnicas de criopreservação testicular, os principais crioprotetores utilizados e os avanços obtidos até o presente momento nas diferentes espécies animais. Na última década, os avanços obtidos com a utilização do tecido testicular para obtenção de células germinativas viáveis e funcionais foram significativos. Todavia, o estabelecimento de protocolos que possam ser utilizados na rotina clínica em diferentes espécies ainda necessitam de maiores esclarecimentos.

Palavras-chave: testículo, conservação, crioprotetores.

\section{INTRODUCTION}

Cryopreservation of testicular tissue is a technique that can facilitate the preservation of reproductive potential in different animal species (OLIVEIRA, 2015). Testicular tissue contains spermatogonia, primary cells that give rise to sperm via the spermatogenesis process. This tissue can be cryopreserved, and spermatogenesis can be completed in vitro after thawing it. Spermatozoa obtained from the culture medium can be used in animal breeding programs through techniques such as intracytoplasmic sperm injection (YOKONISHI et al., 2014). This biotechnology is the only way to preserve the fertility of deceased prepubertal animals, and thus plays a very important role in spreading the genetic material of wild and domestic animals (PUKAZHENTHI et al., 2015).

Cryopreservation of testicular tissue can be accomplished using techniques such as slow freezing, rapid freezing, and vitrification. However, the protocols currently used are still being tested in several species (ABRISHAMI et al., 2010a; BUARPUNG et al., 2013).

The use of cryoprotectant agents (CPAs) in testicular cryopreservation protocols is a major step towards maintenance of cell viability after the tissue has been thawed because CPAs prevent some of the 
damage caused during the thawing process. Several CPAs have been tested in tissue preservation protocols; however, an ideal CPA or CPA association that can be used to maintain the quality and viability of testicular cells were not reported (UNNI et al., 2012).

In this light, the objective of this study is to describe the main biotechnologies applied in testicular cryopreservation of different animal species, and the progress made in obtaining mature sperm from testicular fragments and cell suspensions kept in culture media.

\section{Testicular tissue to preserve fertility}

Testicles are reproductive organs in which sperms are produced and stored, and androgen hormones are produced. Male reproductive gonads are morphologically divided into a tubular region and an intertubular region. Tubular region is where the seminiferous tubules are inserted and where spermatogonial stem cells undergo structural and functional changes until they reach their final sperm form. Intertubular region provides protection to the seminiferous tubules, and corresponds to the region where the male hormones are produced. Groups of cells with different functions can be found in the testicles, and among them, the germ cells, Sertoli cells, and Leydig cells are involved the production of spermatozoa and hormones (JOHNSTON et al., 2001).

Cryopreservation of testicular tissue fragments is used as a tool for preserving the fertility of prematurely dead animals, as well as those undergoing treatments that cause infertility, such as cancer treatment (HOVATTA, 2003). Spermatogenic cells present in cryopreserved testicular fragments can resume their functions in vitro after the testicular fragments have been thawed, contributing to the preservation of fertility and genetic resources of animals considered to be of high genetic value (PUKAZHENTHI et al., 2015), as well as the preservation of those considered endangered wild species (THUWANUT et al., 2013).

\section{Cryopreservation methods of testicular tissue}

Cryopreservation of testicular tissue has emerged as an alternative for fertility preservation, particularly in prepubertal animals (GOOSSENS et al., 2008), allowing the indefinite viability of the genetic material present in the testicles of these animals. The maintenance of this tissue in liquid nitrogen enables its further use in artificial breeding programs (POELS et al., 2012).

The two most common methods to cryopreserve testicular fragments are slow freezing and vitrification (ABRISHAMI et al, 2010a; CURABA et al, 2011a.). Slow freezing is being more frequently used in studies as compared to vitrification; although, both methods are being tested (WYNS et al., 2013). Another technique that has also been used in some experiments is the rapid freezing (GOUK et al, 2011; BUARPUNG et al, 2013).

Slow freezing is performed using a machine that gradually reduces the temperature to which the testicular fragments are exposed. The fragments are initially exposed to an equilibrium solution containing CPAs at $4^{\circ} \mathrm{C}$ for $10-15$ minutes and are then subjected to controlled temperature reduction to reach the frozen state, after which they are transferred to cryovials and stored in liquid nitrogen (GURINA et al., 2011).

There are different protocols for this method of cryopreservation. The protocol by YILDIZ et al. (2013) involved the use of a programmable freezer to subject the testicular fragments of mice to slow freezing. After the fragments passed through the equilibrium solution at $4^{\circ} \mathrm{C}$, they were subjected to a temperature reduction of $-1{ }^{\circ} \mathrm{C}$ minute ${ }^{-1}$ until the temperature reached $0^{\circ} \mathrm{C}$, and this temperature was maintained for 5 minutes. Fragments were then subjected to a temperature reduction of $-0.5^{\circ} \mathrm{C}_{\text {minute }}{ }^{-1}$ until the temperature reached $-8^{\circ} \mathrm{C}$. After 15 minutes at this temperature, the rate of temperature decrease was maintained at $0.5^{\circ} \mathrm{C}$ minute ${ }^{-1}$ until it reached $-40^{\circ} \mathrm{C}$, and this temperature was maintained for 10 minutes. Subsequently, the fragments were subjected to a temperature reduction of $-7^{\circ} \mathrm{C}$ minute ${ }^{-1}$ until the temperature reached $-80^{\circ} \mathrm{C}$, and the fragments were immediately transferred to liquid nitrogen.

This method allows tissue to be less exposed to the deleterious effects of CPAs. However, the possibility of ice crystal formation during the cryopreservation process is relatively high, which might prevent the use of the tissue after it is thawed. Still, it is a highly specialized procedure with equally high cost (WYNS et al., 2013).

In rapid freezing, the fragments are also exposed to the equilibrium solution, but for a period longer than 30 minutes. The fragments are then kept in nitrogen vapor at $4-5 \mathrm{~cm}$ above the liquid column for 10 minutes, after which they are allocated to cryotubes and dipped in liquid nitrogen (THUWANUT et al., 2013). Avoiding cryoinjuries during the cryopreservation steps is the biggest challenge faced when using this technique (BUARPUNG et al., 2013).

Vitrification is a widely used technique in the cryopreservation of female gonadal tissue, 
but despite the multiple ways of vitrifying tissue (CARVALHO et al., 2011), in research of testicular cryopreservation, the technique used was vitrification by solid surface (ABRISHAMI et al., 2010a). This technique is characterized by the exposure of tissue fragments to an equilibrium solution with reduced concentrations of CPA for 5-10 minutes, with the initial concentration being comprised of $50 \%$ of the total CPA volume. Fragments are then exposed to a vitrification solution containing $100 \%$ of the CPAs for 5-10 minutes. Final CPA concentration is high, at more than 30\% (ABRISHAMI et al., 2010, NOHALEZ et al., 2015). The solution containing CPAs is added to cell culture media, along with external CPAs such as sucrose and fetal bovine serum (BAERT et al., 2012). After the testicular tissue is exposed to the vitrification solution, fragments are placed in a metal cube held above liquid nitrogen in an insulated box, which enables the tissue to be cooled ultrarapidly. Upon cooling, these fragments are placed in cryotubes and kept in liquid nitrogen (LIMA et al., 2016). Among all the testicular cryopreservation techniques, vitrification is the one with the lowest operating costs and is the easiest to carry out. It is also more efficient than other techniques in avoiding crystallization due to the ultra-fast cooling rates used. However, exposing tissue to high concentrations of
CPAs can be rather detrimental to the maintenance of morphological and functional characteristics of stem cells (BAERT et al., 2012).

The use of any cryopreservation technique comes with a risk of causing damage to cellular structures, resulting in decreased cell viability. Furthermore, despite the progress made in artificial reproduction using these techniques, there is still lack of a standardized, ideal technique for testicular cryopreservation in different species. Therefore, further research is required to allow for the practical application of testicular cryopreservation in the artificial reproduction of domestic and wild animals (CARVALHO et al., 2011). Studies have been carried out using different cryopreservation methods to evaluate the cryo-sensitivity of testicular tissue and to determine which cryopreservation protocols are effective in different species (Table 1). However, the results are conflicting.

GOUK et al. (2011) conducted a study with prepubertal mice, comparing the effect of slow freezing, rapid freezing, and vitrification on the testicular tissue of these animals. Cell viability after thawing was higher in the vitrification group $(95 \%)$ and rapid freezing group (72\%) as compared to the slow freezing group (24\%). In another study, conducted by BAERT et al. (2012), testicular tissue fragments of

Table 1 - Cryoprotectants and testicular cryopreservation techniques applied in different species. DMSO: dimethyl sulfoxide, EG: ethylene glycol, GLY: glycerol, PRO: propanediol, SF: Slow freezing, RF: Rapid freezing, V: Vitrification.

\begin{tabular}{|c|c|c|c|c|}
\hline Species & Cryoprotectant & $\begin{array}{l}\text { Cryopreservation } \\
\text { technique }\end{array}$ & Main results & Authors \\
\hline Cattle (Bos taurus) & DMSO/PRO & SF & $\begin{array}{c}\text { Viability }>58 \% \text { post-thaw with associated } \\
\text { cryoprotectants. }\end{array}$ & $\begin{array}{l}\text { BARBOSA et al., } \\
2011\end{array}$ \\
\hline Mouse (Mus musculus) & $\begin{array}{l}\mathrm{DMSO} / \mathrm{EG} / \mathrm{GLY} \\
\text { /PRO }\end{array}$ & $\mathrm{SF} / \mathrm{RF} / \mathrm{V}$ & $\begin{array}{l}\text { Viability }>95 \% \text { after vitrification, }>80 \% \text { after } \\
\text { rapid freezing, }<25 \% \text { after slow freezing. }\end{array}$ & $\begin{array}{l}\text { GOUK et al., } \\
2011\end{array}$ \\
\hline Sheep (Ovis aries) & DMSO/EG & $\mathrm{SF} / \mathrm{V}$ & Slow freezing retained the testicular tissue best. & $\begin{array}{l}\text { PUKAZHENTHI } \\
\text { et al., } 2015\end{array}$ \\
\hline Wild cats (Felis chaus) & $\mathrm{DMSO} / \mathrm{EG}$ & $\mathrm{SF} / \mathrm{RF}$ & $\begin{array}{l}\text { Rapid freezing caused minor damage to the } \\
\text { sperm membrane. }\end{array}$ & $\begin{array}{l}\text { THUWANUT et } \\
\text { al., } 2013\end{array}$ \\
\hline $\begin{array}{l}\text { Domestic cat (Felis } \\
\text { silvestres catus) }\end{array}$ & DMSO/EG/GLY & $\mathrm{V}$ & $\begin{array}{l}\text { Association DMSO/GLY provided better } \\
\text { preservation of the morphology of the } \\
\text { seminiferous tubules and a higher percentage of } \\
\text { potential cell proliferation. }\end{array}$ & LIMA et al., 2016 \\
\hline Human (Homo sapiens) & $\mathrm{DMSO} / \mathrm{EG}$ & $\mathrm{SF} / \mathrm{V}$ & $\begin{array}{l}\text { There were no differences between the } \\
\text { cryopreservation techniques. }\end{array}$ & $\begin{array}{l}\text { CURABA et al., } \\
2011 \mathrm{~b}\end{array}$ \\
\hline $\begin{array}{l}\text { Monkey } \quad(\text { Macaca } \\
\text { mulatta })\end{array}$ & $\mathrm{DMSO} / \mathrm{EG}$ & $\mathrm{V}$ & $\begin{array}{l}\text { There were no differences between the fresh } \\
\text { group and vitrified group. }\end{array}$ & $\begin{array}{l}\text { POELS et al., } \\
2012\end{array}$ \\
\hline Pig (Sus domestica) & DMSO/EG/GLY & $\mathrm{SF} / \mathrm{V}$ & $\begin{array}{l}\text { GLY resulted in higher cell viability after slow } \\
\text { freezing. DMSO led to increased cell viability } \\
\text { after vitrification. }\end{array}$ & $\begin{array}{l}\text { ABRISHAMI et } \\
\text { al., 2010a }\end{array}$ \\
\hline Rat (Rattus norvegicus) & DMSO/GLY/EG & SF & $\begin{array}{l}\text { DMSO best preserved immature testicular tissue } \\
\text { and EG best preserved mature testicular tissue. }\end{array}$ & UNNI et al., 2012 \\
\hline
\end{tabular}


prepubertal mice were used to compare the effect of slow freezing and vitrification on the cellular integrity of seminiferous tubules after thawing. Results of this study showed no significant difference between the two techniques. Despite damage to tissue integrity after the cryopreservation process, the tissue structures met the minimum morphological standards necessary for later use in both techniques. ABRISHAMI et al. (2010a) subjected prepubertal pig testicular tissue to either slow freezing or vitrification, and reported that both techniques were effective in preserving cell development potential after thawing.

In a study with domestic cats, BUARPUNG et al. (2013) used pubescent animal testicle fragments to compare slow freezing and rapid freezing. Organelles in testicular tissues subjected to slow freezing showed a significantly lower percentage of plasma membrane integrity (45.9\%) as compared to the control group $(60.3 \%)$ and the rapid freezing group $(55.0 \%)$. There was no difference in DNA fragmentation between the groups.

These results are mostly consistent with those reported by THUWANUT et al. (2013). They assessed the effect of slow and rapid freezing on the testicular tissue of wild cats (Felis chaus; Panthera leo; Panthera pardus), and reported that testicular tissue subjected to rapid freezing had better plasma membrane integrity. They also reported that testicular tissue subjected to slow freezing had significantly lower DNA fragmentation as compared to tissue subjected to rapid freezing.

\section{Cryoprotectant agents}

The cryopreservation process can compromise the function of spermatogenic cells because of their exposure to low temperatures and osmotic imbalances. To minimize the harmful effects of this process, CPAs with intracellular and extracellular activity have been used to preserve organelles present in tissues and keep them functional after the cryopreservation process. However, these agents can also cause cryoinjuries to tissues and cells when added in certain concentrations (UNNI et al., 2012).

Extracellular or non-penetrating CPAs are substances with high molecular weight that contribute to rapid cell dehydration, preventing the formation of ice crystals inside cells (SIEME et al., 2016). One extracellular CPA used in research involving testicular cryopreservation is sucrose, which is always associated with intracellular CPAs in cryoprotectant addition protocols (BAERT et al., 2012).

Intracellular or penetrating CPAs have low molecular weight, which aids in penetration of the cell membrane. They act by preventing the formation of ice crystals inside cells during the cryopreservation process, with minimal effects on cell structure and function (CASTRO et al., 2011). As noted in table 1, the main intracellular CPAs used in the cryopreservation of testicular tissue are dimethyl sulfoxide (DMSO), ethylene glycol, propanediol, and glycerol.

When conducting a comparative study between DMSO and ethylene glycol in the slow freezing of testicular fragments of prepubertal mice (Mus musculus), GOOSSENS et al. (2008) observed better preservation of seminiferous tubules structures after thawing when DMSO was used. A similar result was observed by ABRISHAMI et al. (2010a), who conducted a study involving the slow freezing of prepubertal testicular tissue of pigs (Sus domestica) and observed that testicular fragments cryopreserved with DMSO had a higher percentage of viable cells (75\%) after thawing, as compared to ethylene glycol $(55 \%)$. However, testicular fragments cryopreserved with glycerol in this study, had the highest percentage of viable cells after thawing (88\%).

Results obtained from tissues cryopreserved with DMSO are consistent with those published by UNNI et al. (2012); however, the results obtained in the same study from tissues cryopreserved with glycerol differ. UNNI et al. (2012) evaluated the effects of DMSO, ethylene glycol, and glycerol on the slow freezing of prepubertal testicular tissue fragments of rats (Rattus norvegicus), and they observed that DMSO was less toxic while glycerol was more harmful to cells. However, their assessment of cryopreserved testicular fragments of adult rats showed that DMSO was inferior to ethylene glycol and glycerol as a CPA.

BARBOSA et al. (2011) performed slow freezing of the cell suspension obtained from testicular fragments of adult bovine (Bos taurus) using DMSO and propanediol. They observed that cryopreservation with DMSO resulted in lower cell viability (51.7\%), and cryopreservation using both CPAs resulted in a higher percentage $(58.8 \%)$ of viable sperm after thawing.

Results are consistent with those published by BUARPUNG et al. (2013), who compared the slow freezing of testicular tissue of adult cats (Felis silvestres catus) with cryopreservation using DMSO, ethylene glycol, glycerol, and propanediol. They observed that cryopreservation with DMSO resulted in the lowest maintenance of membrane integrity after thawing. The best results were obtained with glycerol and ethylene glycol. There was no difference between the CPAs in terms of DNA fragmentation. YILDIZ 
et al. (2013); however, observed higher cell viability and preservation of tissue structure with DMSO when comparing these four CPAs in the slow freezing of testicular fragments from mice.

Testicular fragments are subjected to ultra-fast cooling in vitrification. Thus, a greater concentration of CPAs must be used in order to maintain tissue integrity. However, CPAs have deleterious effects on testicular tissue when used in high concentrations. A way to minimize the negative effects of CPAs is to carry out vitrification using associations of different CPAs (POELS et al., 2012; PUKAZHENTHI et al., 2015). Literature comparing different CPAs in the vitrification of testicular tissue is scarce. ABRISHAMI et al. (2010a) conducted a survey to compare the combination of DMSO and glycerol with ethylene glycol in the vitrification of testicular tissue from prepubertal pigs, and reported no significant difference in cell viability when they used different protocols. Conversely, GOUK et al. (2011), when comparing different CPAs used in isolation in the vitrification of testicular fragments of prepubescent mice, observed higher cell viability when ethylene glycol was used as compared to DMSO, glycerol, and propanediol.

Few studies have been conducted relatively recently to compare the effect of CPAs on testicular tissue in prepubertal and pubertal animals. However, it is evident that CPAs have different effects on testicular tissue in prepubertal and pubertal animals. UNNI et al. (2012) observed higher sensitivity of immature tissue to the toxic effects of CPAs as compared to that by mature tissue. They observed that the seminiferous tubules of immature tissue are better protected in the presence of DMSO, and those of mature tissue are better protected with ethylene glycol. MOTA et al. (2012) cryopreserved fragments of testicular tissue of prepubertal and pubertal domestic cats with DMSO, followed by subsequent xenografts in immunocompromised mice. They observed that the tissue from prepubertal animals showed an increased amount of stem cells and the presence of seminiferous tubules as compared to those from pubescent animals 10 weeks after the xenograft.

The results observed in different species are conflicting. For reproductive biology to be successful, cells present in tissues need to be viable and functional after being subjected to thermal stress. Therefore, it is important to carry out more research to addresses the application of CPAs in testicular fragment cryopreservation protocols.

\section{Advances and perspectives in testicular cryopreservation}

Researches involving testicular cryopreservation have made use of xenotransplantation techniques or in vitro cell culture to obtain viable and functional sperm cells for use in assisted reproduction programs after tissue cryopreservation (YOKONISHI et al., 2014; POTHANA et al., 2015). Organ transplantation across species, or xenotransplantation, has been used as a cell culture medium ex situ in different species. This technique has contributed to the field of animal breeding, as it allows sperm cells to be obtained from prepubertal animals. However, its application in assisted reproduction programs is still restricted to the experimental field (MOTA et al., 2012).

In gametogenesis, cells are subjected to the action of different hormones, mainly the gonadotropins. The hormonal activity in prepubertal animals is not compatible with the cell differentiation necessary for obtaining spermatozoa. Thus, after cryopreservation, the tissue fragments transplanted into the body of pubescent animals of other species have to be exposed to the hormonal activity needed to progress through different stages of spermatogenesis (ABBASI \& HONARAMOOZ, 2011).

Testicular tissue of immature animals that have been ectopically transplanted into immunocompromised mice can respond to gonadotropin present in mice, thus allowing for complete differentiation into sperm capable of performing fertilization. In light of this, various methods have been developed to take advantage of the biological material from prepubertal animals with high genetic value, or wild animals that have died prematurely (RODRIGUEZ-SOSA \& DOBRINSKI, 2009).

In this context, ABRISHAMI et al. (2010b) conducted a study involving xenografts of cryopreserved testicular fragments of 2-month-old domestic dogs in the subcutaneous tissue of mice. After 13 months of culture, fully formed spermatozoa were recovered in 5 of the 29 implanted fragments. POTHANA et al. (2015) used cryopreserved testicular fragments of Indian deer (Moschiola indica) for xenograft transplants in immunocompromised mice, and obtained primary spermatocytes after 24 weeks of implantation.

ABRISHAMI et al. (2010a) grafted cryopreserved testicular tissue from prepubertal pigs into mice. After 16 weeks, they observed the presence of elongated spermatids in the recovered testicular tissue fragments. Conversely, MOTA et 
al. (2012) conducted an experiment using pubertal and prepubertal cryopreserved testicular tissue of cats transplanted subcutaneously in mice. After 10 weeks, they observed that the fragments did not have seminiferous tubules with germ cells.

Prepubescent testicular tissue can be fragmented after cryopreservation, allowing a cell suspension containing spermatogonia to be obtained. These cells can be maintained in cell culture plates under conditions that favour their differentiation into viable sperm for artificial insemination (YOKONISHI et al., 2014).

Gametogenesis is a complex process involving cell migration to different sites, cell proliferation and differentiation, as well as interaction between different cell types (RODRIGUEZ-SOSA \& DOBRINSKI, 2009). Few studies have been carried out using testicular tissue in cell culture, but these studies have demonstrated the ability of primordial germ cells to differentiate into more advanced cell stages (VISINTIN et al., 2013). For reproductive biotechnology to be successful, it is necessary for the culture medium to allow for cell survival and differentiation. Culture medium must contain nutrients and substances that mimic the natural site of cellular development. Thus, it is essential to add gonadotropic hormones to the culture media, so as to provide conditions favouring the proliferation and differentiation of germ cells and ensuring success in obtaining functional sperm (MURTA et al., 2013).

In a study by MILAZZO et al. (2008), fresh and cryopreserved testicular tissue fragments of prepubertal mice were cultured for 9 days in a humidified $\mathrm{CO}_{2}$ chamber at $5 \%$. Culture medium consisted of minimal essential medium (MEM), antioxidants, and antibiotics with the addition of 50IU $\mathrm{L}^{-1}$ of follicle-stimulating hormone (FSH) and 5IU L $\mathrm{L}^{-1}$ of luteinizing hormone (LH). The authors evaluated the effect of cryopreservation on testosterone production, cell proliferation, and growth of the seminiferous tubules in cryopreserved and fresh testicular tissue fragments, but did not observe any difference. Spermatocytes were observed in both groups after a period of cell culture.

SATO et al. (2011) cultured cryopreserved testicular tissue of immature mice. They added FSH (200ng $\left.\mathrm{ml}^{-1}\right)$ and testosterone $(1 \mu \mathrm{M})$ to the cell culture medium and could obtain sperm for up to 60 days of culture. They obtained healthy offspring after performing artificial insemination through sperm microinsemination.

Research
cryopreservation has contributed to significant

advancement in this field in the last decade. BUARPUNG et al. (2013) demonstrated the sperm fertilizing capacity of testicular tissue of domestic pubescent cats. Cells obtained from thawed testicular tissue were used for in vitro fertilization of mature oocytes, and progression to the blastocyst stage occurred in $14 \%$ of cleaved embryos, which is similar to that observed for the control group.

YOKONISHI et al. (2014) demonstrated the applicability of this reproductive biotechnology in an experiment using prepubertal mice as a model for humans. Cryopreserved testicular fragments were thawed and cultured in vitro to obtain sperm. These cells were used to inseminate female mice, resulting in a brood of eight puppies. When these puppies reached the adult stage, they bred and produced normal, healthy offspring.

Despite the success in these studies, there is still a need to improve on existing cryoprotectant protocols and develop cryopreservation techniques better suited for the preservation of testicular tissue of different species. This remains a major challenge in the preservation of fertile animals with superior genetics, preservation of human reproductive health, as well as in the establishment of cryobanks for wildlife (HOLOCH \& WALD, 2011; UNNI et al., 2012; THUWANUT et al., 2013; BAERT et al., 2015).

\section{CONCLUSION}

Cryopreservation of testicular tissue can be considered an alternative means of maintaining the fertilizing capacity of pubescent animals, and it is the only method by which prepubertal prematurely deceased animals can spread their genetic material to future generations. Breakthroughs in the development of cryopreservation technologies have enabled sperm to be produced from cryopreserved tissue in different species. However, there are still challenges in applying this knowledge into practice. Thus, there is a need for further research to determine how CPAs can be better used in cryopreservation, and for the development of better cryopreservation techniques.

\section{ACKNOWLEDGEMENTS}

The authors are grateful to Coordenação de Aperfeiçoamento de Pessoal de Nível Superior (CAPES) for granting a scholarship during this study. Process number 1543413.

\section{REFERENCES}

ABBASI, S.; HONARAMOOZ, A. Xenografting of testis tissue from bison calf donos into recipient mice as a strategy for salvaging genetic material. Theriogenology, v.76, p.607-614, 
2011. Available from: <http://www.theriojournal.com/article/ S0093-691X(11)00147-6/pdf>. Accessed: Sept. 25, 2016. doi: 10.1016/j.theriogenology.2011.03.011.

ABRISHAMI, M. et al. Cryopreservation of immature porcine testis tissue to maintain its developmental potential after xenografting into recipient mice. Theriogenology, v.73, n.1, p.86-96, 2010a. Available from: $<$ http://www.sciencedirect.com/science/article/pii/ S0093691X09003902>. Accessed: June 08, 2015. doi: 10.1016/j. theriogenology.2009.08.004.

ABRISHAMI, M. et al. The effect of donor age on progression of spermatogenesis in canine testicular tissue after xenografting into immunodeficient mice. Theriogenology, v.73, n.4, p.512-522, 2010b. Available from: <http://www.theriojournal.com/article/ S0093-691X(09)00466-X/pdf>. Accessed: Sept. 25, 2016. doi: 10.1016/j.theriogenology.2009.09.035.

BAERT, Y. et al. Orthotopic grafting of cryopreserved prepubertal testicular tissue: in search of a simple yet effective cryopreservation protocol. Fertility and Sterility, v.97, n.5, p.1152-1157, 2012. Available from: $<$ http://www.sciencedirect.com/science/article/pii/ S0015028212002245>. Accessed: Jan. 28, 2016. doi: 10.1016/j. fertnstert.2012.02.010

BAERT, Y. et al. Cryopreservation of testicular tissue before long-term testicular cell culture does not alter in vitro cell dynamics. Fertility and Sterility, v.104, n.5, p.1244-1252, 2015. Available from: <http://www.sciencedirect.com/science/ article/pii/S0015028215016453>. Accessed: Feb. 23, 2016. doi: 10.1016/j.fertnstert.2015.07.1134

BARBOSA, A.P.M. et al. Cryopreservation of bovine spermatogenic cells using different protective molecules. Archivos de Zootecnia, v.60, n.230, p.293-296, 2011. Available from: <http://www.uco.es/ organiza/servicios/publica/az/php/img/web/19_20_25_14NotaCri opreservacaoBarbosa.pdf $>$. Accessed: Jan. 28, $201 \overline{6}$.

BUARPUNG, S. et al. Feline spermatozoa from fresh and cryopreserved testicular tissues have comparable ability to fertilize matured oocytes and sustain the embryo development after intracytoplasmic sperm injection. Theriogenology, v.79, n.1, p.149-158, 2013. Available from: <http://www.sciencedirect. com/science/article/pii/S0093691X12005444>. Accessed: Jan. 28, 2016. doi: 10.1016/j.theriogenology.2012.09.022.

CARVALHO, A.A. et al. Vitrification: an alternative for preserving embryos and genetic material mammalian females in cryobanking. Acta Veterinaria Brasilica, v.5, n.3, p.236-248, 2011. Available from: $\quad<$ http://periodicos.ufersa.edu.br/revistas/index.php/acta/ article/view/2321>. Accessed: Jan. 31, 2016.

CASTRO, S.V. et al. Agentes crioprotetores intracelulares: características e utilização na criopreservação de tecido ovariano e oócitos. Acta Scientiae Veterinariae, v.39, n.2, p.1-17, 2011. Available from: < http://www.ufrgs.br/actavet/39-2/PUB\%20957. pdf>. Accessed: Feb. 23, 2016.

CURABA, M. et al. Cryopreservation of prepubertal mouse testicular tissue by vitrification. Fertility and Sterility, v.95, n.4, p.1229-1234, 2011a. Available from: <http://www.sciencedirect. com/science/article/pii/S0015028210007004> . Accessed: Oct. 19, 2015. doi: 10.1016/j.fertnstert.2010.04.062.

CURABA, M. et al. Can prepubertal human testicular tissue be cryopreserved by vitrification? Fertility and Sterility, v.95, n.6, p.9-12, 2011b. Available from: <http://www.sciencedirect.com/ science/article/pii/S0015028211000240>. Accessed: Feb. 23, 2016. doi: 10.1016/j.fertnstert.2011.01.014.

GOOSSENS, E. et al. Cryosurvival and spermatogenesis after allografting prepubertal mouse tissue: comparison of two cryopreservation protocols. Fertility and Sterility, v.89, n.3, p.725-727, 2008. Available from: <http://www.sciencedirect. com/science/article/pii/S0015028207006620>. Accessed: Jan. 28, 2016. doi: 10.1016/j.fertnstert.2007.03.044.

GOUK, S.S. et al. Cryopreservation of mouse testicular tissue: prospect for harvesting spermatogonial stem cells for fertility preservation. Fertility and Sterility, v.95, n.7, p.2399-2403, 2011. Available from: $<$ http://www.sciencedirect.com/science/article/pii/ S0015028211004444>. Accessed: Feb. 23, 2016. doi: 10.1016/j. fertnstert.2011.03.035.

GURINA, T.M. et al. Development of a cryopreservation protocol for testicular interstitial cells with the account of temperature intervals for controlled cooling below $-60^{\circ} \mathrm{C}$. Cryobiology, v. 62 , p.107-114, 2011. Available from: <http://www.sciencedirect.com/ science/article/pii/S0011224011000125>. Accessed: Jan. 28, 2016. doi: 10.1016/j.cryobiol.2011.01.011

HOLOCH, P.; WALD, M. Current options for preservation of fertility in the male. Fertility and Sterility, v.96, n.2, p.286-290, 2011. Available from: <http://www.sciencedirect.com/science/ article/pii/S0015028211009733>. Accessed: June 17, 2015. doi: 10.1016/j.fertnstert.2011.06.028.

HOVATTA, O. Cryobiology of ovarian and testicular tissue. Best Practice \& Research Clinical Obstetrics \& Gynaecology, v.17, n.2, p.331-342, 2003. Available from: <http://www. bestpracticeobgyn.com/article/S1521-6934\%2802\%29001256/abstract>. Accessed: Jan. 31, 2016. doi: 10.1016/S15216934(02)00125-6

JOHNSTON, S.D. et al. Canine and feline theriogenology. Philadelphia: Saunders, 2001. 592p.

LIMA, D.B.C. et al. Different associations of cryoprotectants for testicular tissue of prepubertal cats submitted to vitrification. Reproduction in Domestic Animals, v.51, p.1-7, 2016. Available from: <http://onlinelibrary.wiley.com/doi/10.1111/rda.12833/pdf>. Accessed: Nov. 09, 2016. doi: 10.1111/rda.12833.

MILAZZO, J.P. et al. Comparison of conditions for cryopreservation of testicular tissue from immature mice. Human Reproduction, v.23, p.17-28, 2008. Available from: <https://academic.oup.com/ humrep/article/23/1/17/563606/Comparison-of-conditions-forcryopreservation-of $>$. Accessed: Sept. 30, 2016. doi: 10.1093/ humrep/dem 355 .

MOTA, P.C. et al. Effects of different storage protocols on cat testis tissue potential for xenografting and recovery of spermatogenesis. Theriogenology, v.77, n.2, p.299-310, 2012. Available from: $<$ http://www.sciencedirect.com/science/article/pii/ S0093691X11003918>. Accessed: Jan. 28, 2016. doi: 10.1016/j. theriogenology.2011.07.042.

MURTA, D.V.F. et al. Organização celular dos testículos de mamíferos. Revista Científica Eletrônica de Medicina Veterinária, v.11, n.20, p.1-12, 2013. Available from: <http://faef. revista.inf.br/imagens_arquivos/arquivos_destaque/0PbEOm8vhp KbA8V_2013-6-21-15-52-4.pdf>. Accessed: Jan. 31, 2016. 
NOHALEZ, A. et al. Effects of two combinations of cryoprotectants on the in vitro developmental capacity of vitrified immature porcine oocytes. Theriogenology, v.84, p.545-552, 2015. Disponível em: <http://www.theriojournal.com/article/S0093691X(15)00186-7/pdf>. Accessed: May 16, 2016. doi: 10.1016/j. theriogenology.2015.04.004.

OLIVEIRA, E.C.S. Criopreservação de tecido testicular. Revista Brasileira de Reprodução Animal, v.39, n.1, p.109-110, 2015. Available from: <http://www.cbra.org.br/pages/publicacoes/rbra/ v39n1/pag109-110\%20(RB557).pdf>. Accessed: Feb. 03, 2016.

POELS, J. et al. Vitrification of non-human primate immature testicular tissue allows maintenance of proliferating spermatogonial cells after xenografting to recipient mice. Theriogenology, v.77, n.5, p.1008-1013, 2012. Available from: <http://www.sciencedirect. com/science/article/pii/S0093691X11005309>. Accessed: Jan. 28, 2016. doi: 10.1016/j.theriogenology.2011.10.015.

POTHANA, L. et al. Germ cell differentiation in cryopreserved, immature, indian spotted mouse deer (Moschiola indica) testes xenografted onto mice. Theriogenology, v.83, n.4, p.625-633, 2015. Available from: <http://www.theriojournal.com/article/ S0093-691X(14)00581-0/fulltext>. Accessed: Sept. 25, 2016. doi: 10.1016/j.theriogenology.2014.10.028.

PUKAZHENTHI, B.S. et al. Slow freesing, but not vitrification supports complete spermatogenesis in cryopreserved, neonatal sheep testicular xenografts. Plos One, v.10, n.4, p.115, 2015. Available from: <http://journals.plos.org/plosone/ article $\mathrm{id}=10.1371$ journal.pone.0123957>. Accessed: Jan. 28, 2016. doi: 10.1371/journal.pone.0123957.

RODRIGUEZ-SOSA, J.R.; DOBRINSKI, I. Recent developments in testis tissue xenografting. Reproduction, v.138, p.187-194, 2009. Available from: <http://www.reproduction-online.org/ content/138/2/187.full.pdf+html>. Accessed: Sept. 25, 2016.

SATO, T. et al. In vitro production of functional sperm in cultured neonatal mouse testes. Nature, v.471, p.504-508, 2011. Available from: < http://www.nature.com/nature/journal/v471/ n7339/full/nature09850.html>. Accessed: Sept. 30, 2016. doi: 10.1038 /nature 09850 .
SIEME, H. et al. Mode of action of cryoprotectants for sperm preservation. Animal Reproduction Science, v.169, p.2-5, 2016. Available from: $<$ http://www.sciencedirect.com/science/article/pii/ S0378432016300343>. Accessed: Feb. 23, 2016. doi: 10.1016/j. anireprosci.2016.02.004

THUWANUT, P. et al. Sperm quality and the morphology of cryopreserved testicular tissues recovered post-mortem from diverse wild species. Cryobiology, v.67, n.2, p.244-247, 2013. Available from: < http://www.sciencedirect.com/science/article/pii/ S0011224013001934>. Accessed: Jan. 28, 2016. doi: 10.1016/j. cryobiol.2013.07.002.

UNNI, S. et al. Efficient cryopreservation of testicular tissue: effect of age, sample state, and concentration of cryoprotectant. Fertility and Sterility, v.97, n.1, p.200-208, 2012. Available from: <http:// www.sciencedirect.com/science/article/pii/S0015028211027038>. Accessed: Jan. 28, 2016. doi: 10.1016/j.fertnstert.2011.10.018.

VISINTIN, J.A. et al. Diferenciação de gametas in vitro a partir de células-tronco. Revista Brasileira de Reprodução Animal, v.37, n.2, p.140-144, 2013. Available from: <http://www.cbra.org. br/pages/publicacoes/rbra/v37n2/pag140-144\%20(RB466).pdf $>$. Accessed: Sept. 25, 2016.

WYNS, C. et al. Vitrification du tissu testiculaire: évolution or révolution? Gynécologie Obstétrique \& Fertilité, v.41, n.9, p.558-561, 2013. Available from: <http://www.sciencedirect.com/ science/article/pii/S1297958913001872>. Accessed: Feb. 23, 2016. doi: 10.1016/j.gyobfe.2013.07.005.

YILDIZ, C. et al. Effect of different cryoprotectant agents on spermatogenesis efficiency in cryopreserved and grafted neonatal mouse testicular tissue. Cryobiology, v.67, p.70-75, 2013. Available from: $<$ http://www.sciencedirect.com/science/article/pii/ S0015028211027038>. Accessed: Feb. 23, 2016. doi: 10.1016/j. fertnstert.2011.10.018

YOKONISHI, T. et al. Offspring production with sperm grown in vitro from cryopreserved testis tissues. Nature Communications, v.5, p.1-6, 2014. Available from: <http://www.nature.com/ ncomms/2014/140701/ncomms5320/full/ncomms5320.html>. Accessed: Feb. 05, 2016. doi: 10.1038/ncomms5320. 